
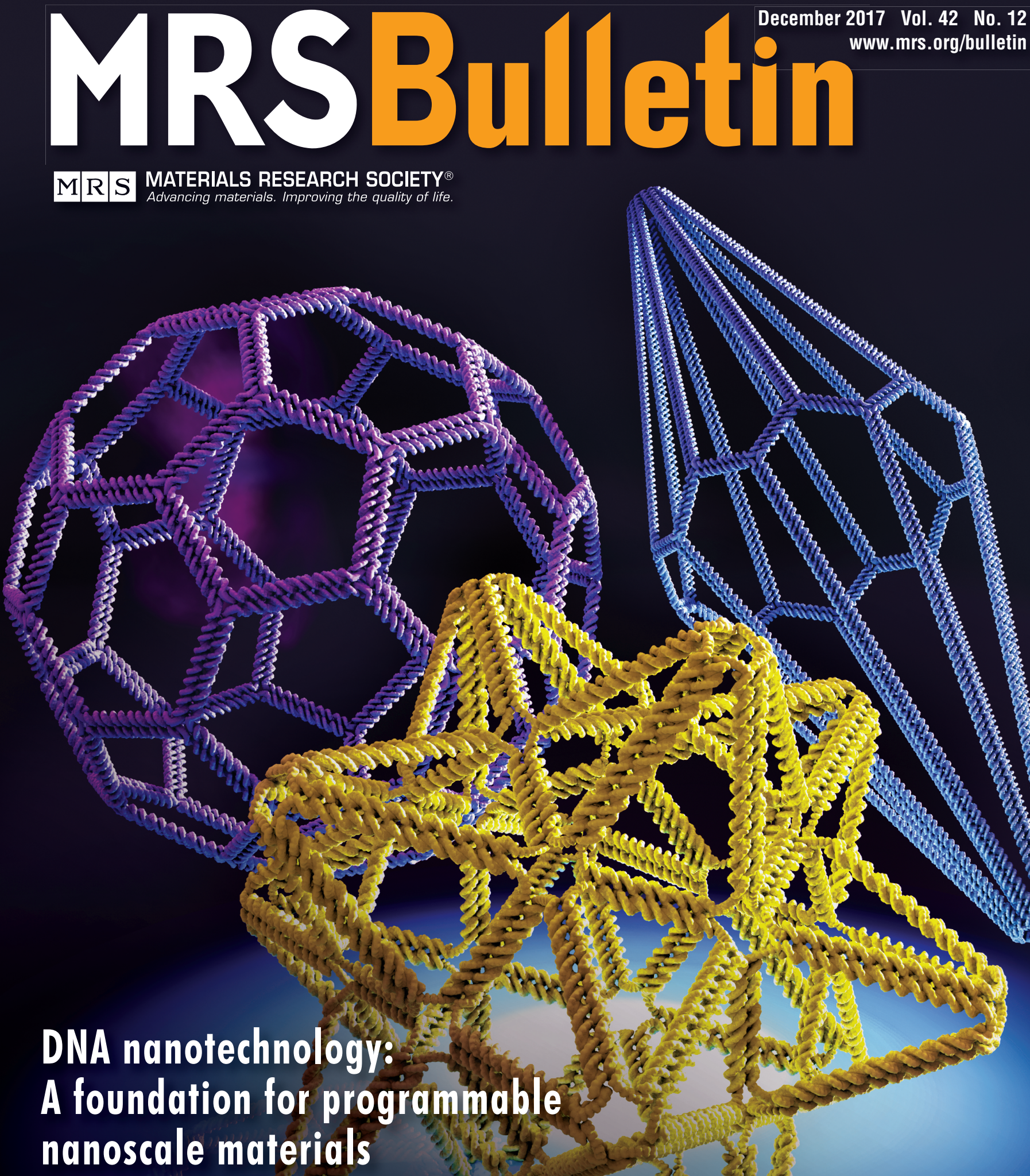

ALSO IN THIS ISSUE

Stretchable bioelectronics
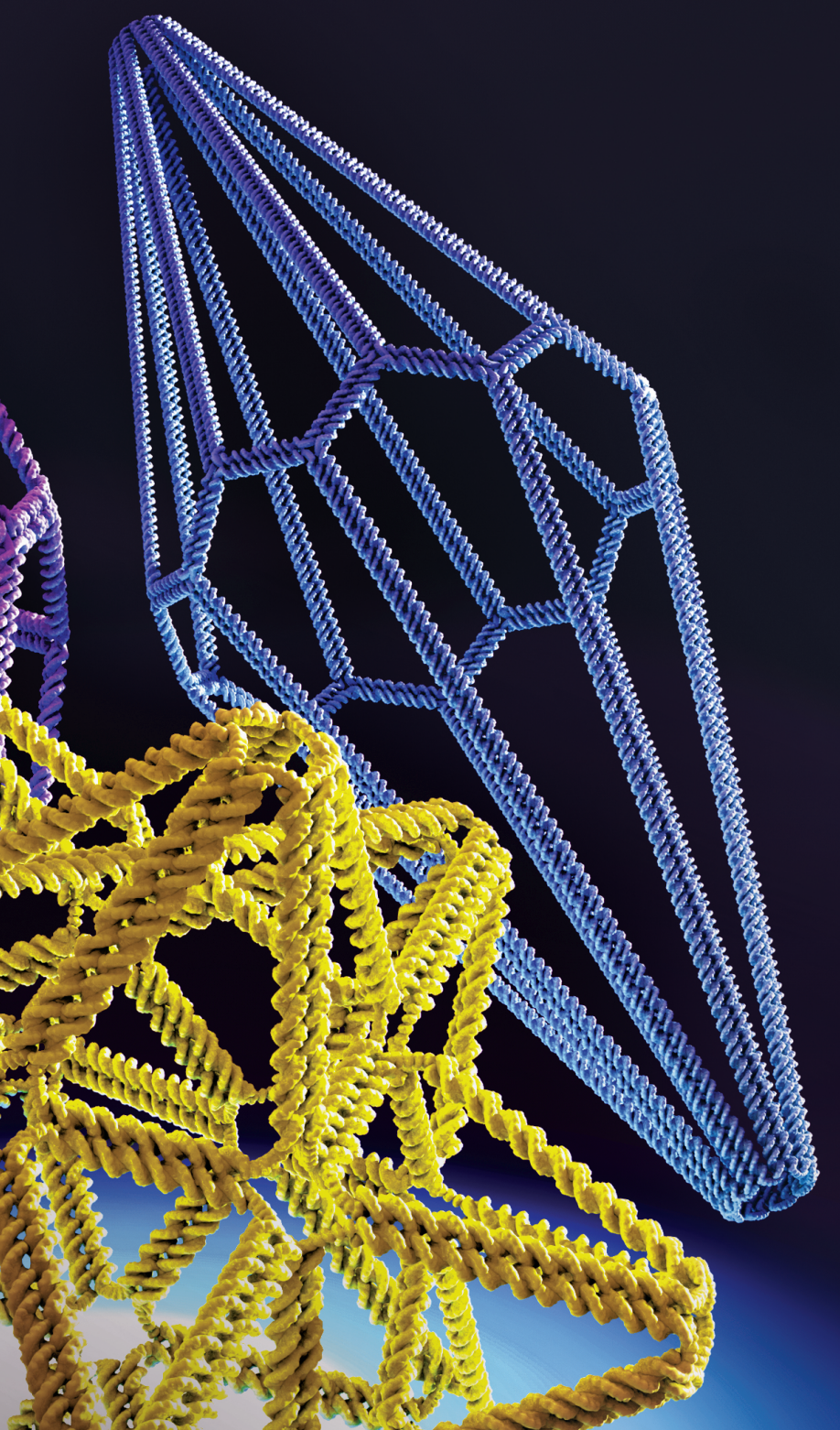

\title{
A foundation for programmable nanoscale materials
}

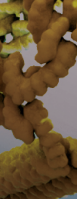




\section{CUSTOMIZED PRODUCTION ION IMPLANTERS}

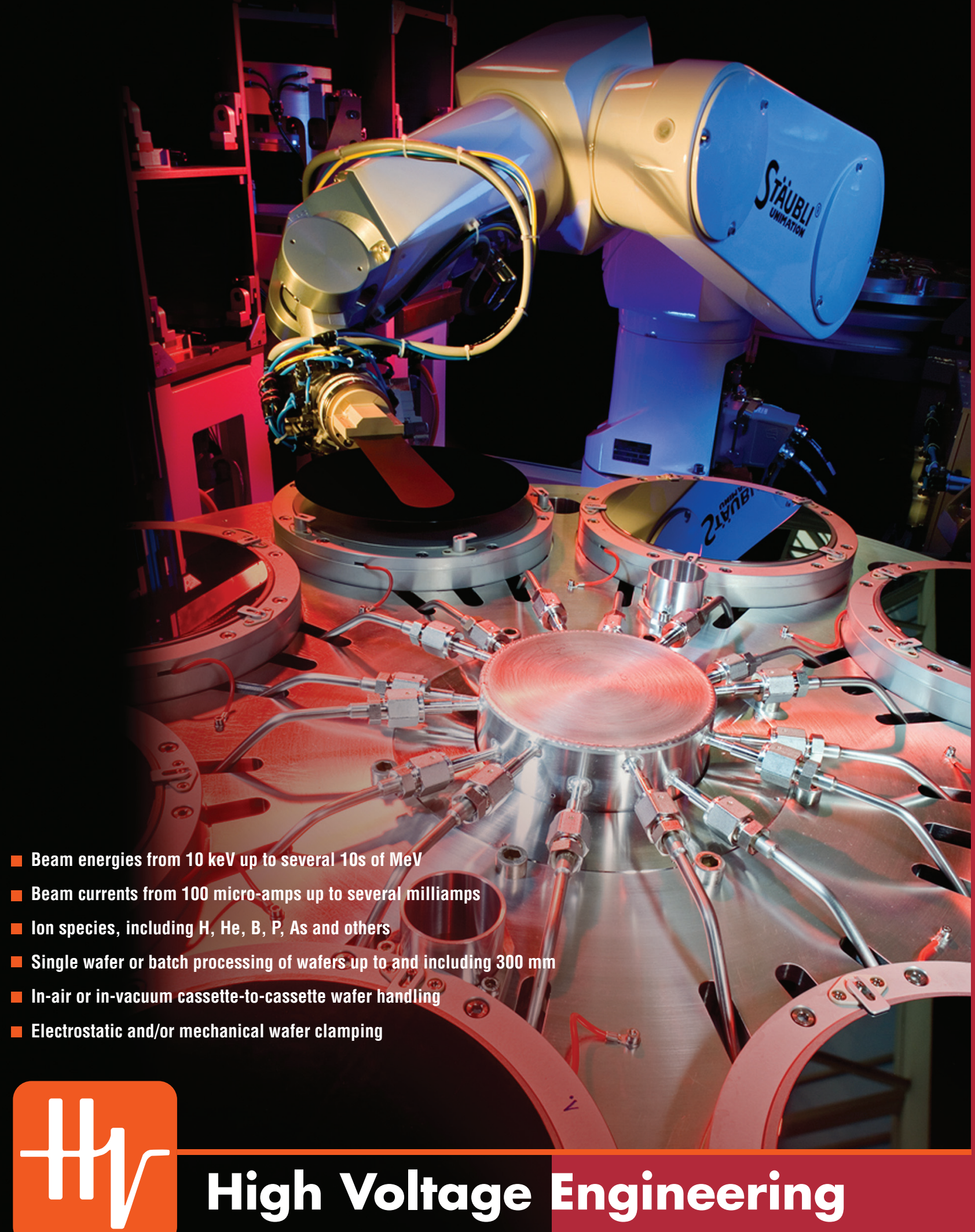

High Voltage Engineering Europa B.V.

P.O. Box 99, 3800 AB Amersfoort, The Netherlands

Tel: 3133 4619741 • info@highvolteng.com

www.highvolteng.com 


\section{Molecular Instruments molecularinstruments.org}

A non-profit academic resource within the Beckman Institute at Caltech

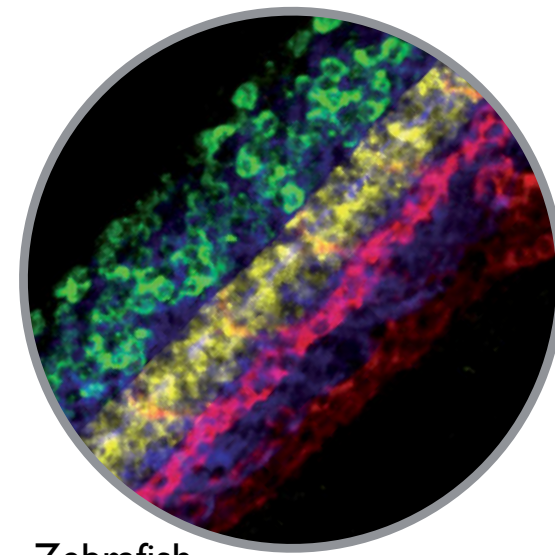

Zebrafish

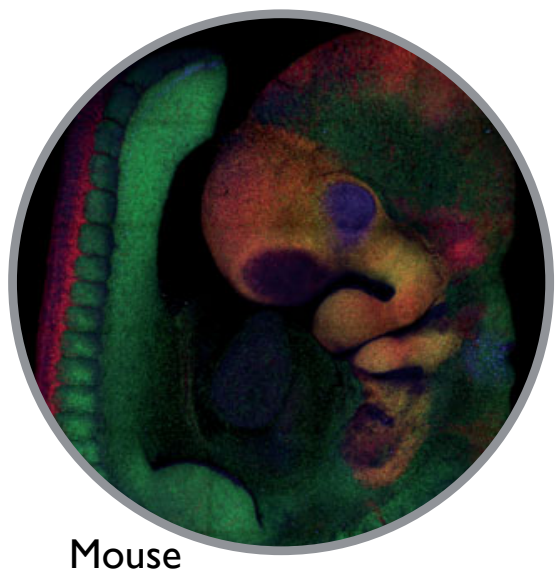

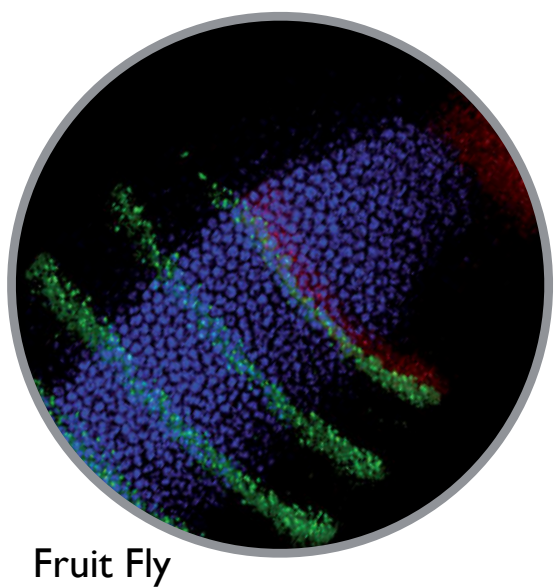

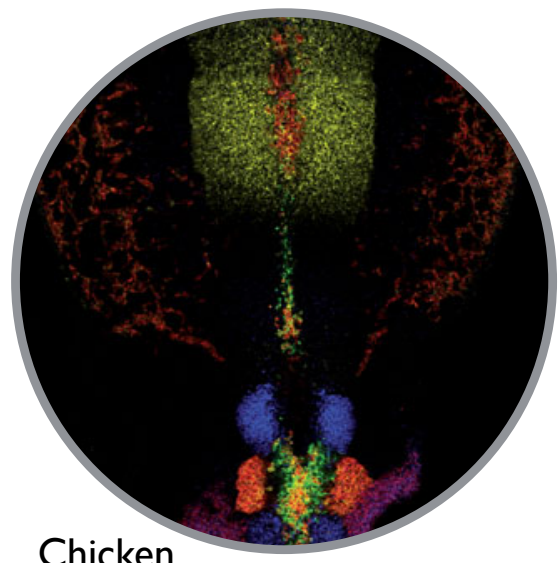

Chicken

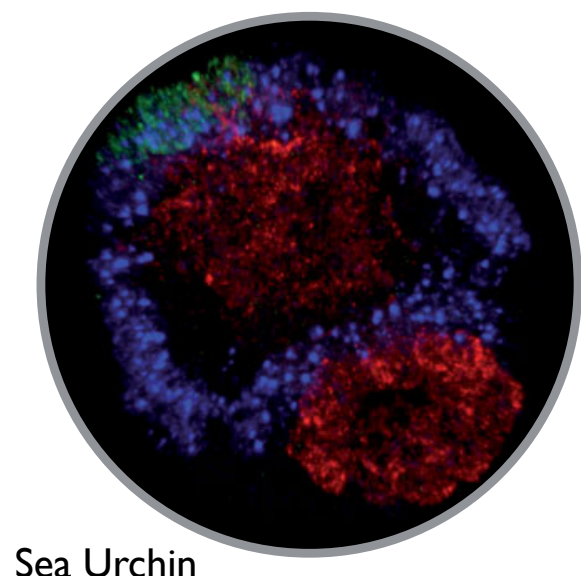

Sea Urchin

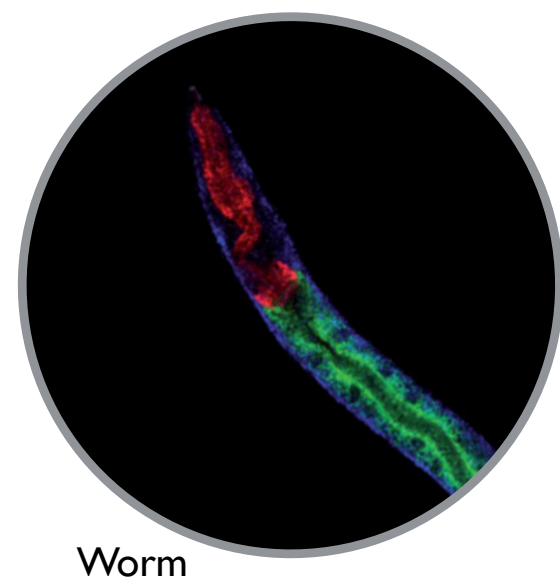

Applying principles from molecular programming and dynamic nucleic acid nanotechnology to develop and support programmable molecular technologies for reading out and regulating the state of endogenous biological circuitry 


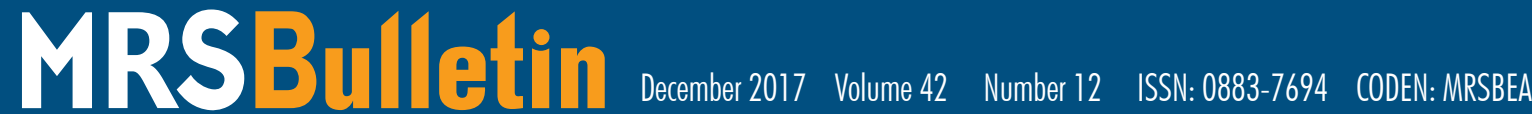
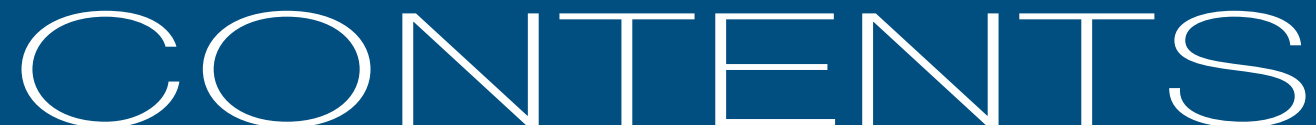

DNA NANOTECHNOLOGY: A FOUNDATION FOR PROGRAMMABLE NANOSCALE MATERIALS

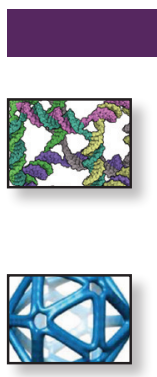

882 DNA nanotechnology: A foundation for programmable nanoscale materials

Mark Bathe and Paul W.K. Rothemund, Guest Editors

889 Practical aspects of structural and dynamic DNA nanotechnology

Pengfei Wang, Gourab Chatterjee, Hao Yan,

Thomas H. LaBean, Andrew J. Turberfield,

Carlos E. Castro, Georg Seelig, and Yonggang Ke

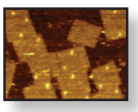

897 Chemical modifications and reactions in DNA nanostructures

Kurt V. Gothelf

904 Three-dimensional molecular and nanoparticle crystallization by DNA nanotechnology Nadrian C. Seeman and Oleg Gang

913 Self-organizing materials built with DNA Friedrich C. Simmel and Rebecca Schulman

920 Enzyme-functionalized DNA nanostructures as tools for organizing and controlling enzymatic reactions

Guido Grossi, Andreas Jaekel, Ebbe Sloth Andersen, and Barbara Saccà

925 DNA origami devices for molecular-scale precision measurements

Carlos E. Castro, Hendrik Dietz, and Björn Högberg

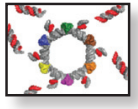

930 RNA nanotechnology - The knots and folds of RNA nanoparticle engineering

Yossi Weizmann and Ebbe Sloth Andersen

936 Sculpting light by arranging optical components with DNA nanostructures Mauricio Pilo-Pais, Guillermo P. Acuna, Philip Tinnefeld, and Tim Liedl
943 DNA origami: The bridge from bottom to top Anqin Xu, John N. Harb, Mauri A. Kostiainen, William L. Hughes, Adam T. Woolley, Haitao Liu, and Ashwin Gopinath

951 Nanometrology and super-resolution imaging with DNA

Elton Graugnard, William L. Hughes, Ralf Jungmann, Mauri A. Kostiainen, and Veikko Linko

\section{TECHNICAL FEATURE}

\section{DOCHNCALFEATURE \\ 960 Stretchable bioelectronics- \\ Current and future \\ Ishan D. Joshipura, Mickey Finn III, Siew Ting Melissa Tan, Michael D. Dickey, and Darren J. Lipomi}

\section{Energy Quarterly}

877 Editorial

Engineering research: An underinvested-in weak link in the energy innovation ecosystem Venkatesh Narayanamurti

878 Energy Sector Analysis Splitting $\mathrm{CO}_{2}$ to produce syngas and hydrocarbon fuels: PEC and STC

Eva Karatairi

FEATURE EDITOR: James E. Miller

880 Energy Sector Analysis

Light-emitting diodes: A case study in engineering research

Prachi Patel

FEATURE EDITOR: Jeffrey Tsao 


\section{DEPARTMENTS}

\section{NEWS \& ANALYSIS}

870 Materials News

- Sponge electrode architecture provides safe, high-performance Ni-3D Zn battery Boris Dyatkin

- Asphalt porous structure enables fast-charging high-capacity Li-metal anode Aashutosh Mistry

- Solidification technique at the nanoscale expands range of 3D-printable alloys Prachi Patel

874 Science Policy

- US government works toward grid modernization Jennifer A. Nekuda Malik

- EC awards Paris as most innovative European city in 2017

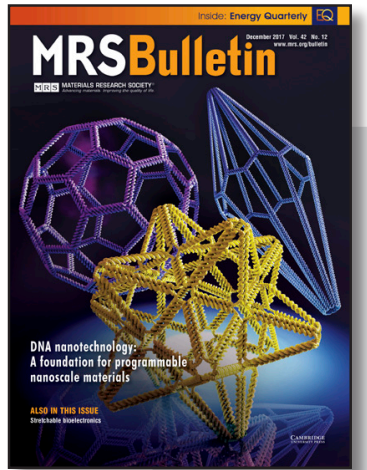

\section{ON THE COVER}

DNA nanotechnology: A foundation for programmable nanoscale materials. This issue of MRS Bulletin overviews the unique capabilities of DNA nanotechnology, with the aim of promoting the integration of DNA nanotechnology into materials science. The focus is on the use of artificial DNA systems to organize and reconfigure functional nanomaterials. The articles in the issue highlight a wide range of applications, from new DNA-based lithographies and plasmonic optical devices to DNA boxes that control the activity of enzymes. The cover illustrates the power and versatility of DNA self-assembly to program nanoscale geometry. Three polyhedra highlight the field's progress toward fully automated design. Each DNA double helix has a diameter of $2 \mathrm{~nm}$, and the maximum dimension of the star is $100 \mathrm{~nm}$. Image courtesy Ella Maru Studio, rendered using atomic models from Sakul Ratanalert, Massachusetts Institute of Technology. See the technical theme that begins on page $\mathbf{8 8 2}$.

\section{SOCIETY NEWS}

- MRS helps bolster materials education in Italy and increase interactions with academia Lori A. Wilson

Profiles

- Katie Van Aken: Materials scientist, budding entrepreneur, and outreach enthusiast Humaira Taz

\section{FEATURES}

\section{Books}

- Patterns in Nature: Why the Natural World Looks the Way It Does

Philip Ball

Reviewed by N. Balasubramanian

- Silicon Light-Emitting Diodes and Lasers: Photon Breeding Devices using Dressed Photons Motoichi Ohtsu Reviewed by Sudip Mukhopadhyay

- Materials: Introduction and Applications Witold Brostow and Haley E. Hagg Lobland Reviewed by Walid M. Daoush

\section{Image Gallery \\ Look Again}

\section{CAREER CENTRAL}

\begin{tabular}{|c|c|}
\hline AUV & \\
\hline \multicolumn{2}{|c|}{ American Elements } \\
\hline & \\
\hline \multicolumn{2}{|c|}{ High Voltage Engineering ............................. Inside front cover } \\
\hline & $\ldots .865$ \\
\hline & \\
\hline & \\
\hline & \\
\hline
\end{tabular}

www.mrs.org/bulletin

www.mrs.org/energy-quarterly

www.mrs.org/mymrs

http://journals.cambridge.org

mrsbulletin-rss

$@$ mrsbulletin 


\section{$\mathrm{M}|\mathrm{R}| \mathrm{S}$}

MATERIALS RESEARCH SOCIETY ${ }^{\circledR}$

Advancing materials. Improving the quality of life.
EDITORIAL OFFICE 506 Keystone Drive, Warrendale, PA 15086-7573 USA Bulletin@mrs.org tel 724.779.2747 fax 724.779.8313 www.mrs.org

\section{About the Materials Research Society}

The Materials Research Society (MRS), a not-for-profit scientific association founded in 1973 and headquartered in Warrendale, Pennsylvania, USA, promotes interdisciplinary materials research. Today, MRS is a growing, vibrant, member-driven organization of over 16,000 materials researchers spanning over 80 countries, from academia, industry, and government, and a recognized leader in the advancement of interdisciplinary materials research.

The Society's interdisciplinary approach differs from that of single-discipline professional societies because it promotes information exchange across many scientific and technical fields touching materials development. MRS conducts three major international annual meetings and also sponsors numerous single-topic scientific meetings. The Society recognizes professional and technical excellence and fosters technical interaction through University Chapters. In the international arena, MRS implements bilateral projects with partner organizations to benefit the worldwide materials community. The Materials Research Society Foundation helps the Society advance its mission by supporting various projects and initiatives.

\section{MRS BOARD OF DIRECTORS}

President Susan Trolier-McKinstry, The Pennsylvania State University, USA Immediate Past President Kristi S. Anseth, University of Colorado Boulder, USA Vice President and President-Elect Sean J. Hearne,

Sandia National Laboratories, USA

Secretary Eric A. Stach, University of Pennsylvania, USA

Treasurer David J. Parrillo, The Dow Chemical Company, USA

Executive Director Todd M. Osman, Materials Research Society, USA

Charles T. Black, Brookhaven National Laboratory, USA

Li-Chyong Chen, National Taiwan University, Taiwan

Matt Copel, IBM T.J. Watson Research Center, USA

Paul S. Drzaic, Apple, Inc., USA

Dawnielle Farrar-Gaines, Johns Hopkins University, USA

Yury Gogotsi, Drexel University, USA

Claudia Gutiérrez-Wing, Instituto Nacional de Investigaciones Nucleares, Mexico

Young-Chang Joo, Seoul National University, South Korea

Karen L. Kavanagh, Simon Fraser University, Canada

Lincoln J. Lauhon, Northwestern University, USA

Christine Ortiz, Massachusetts Institute of Technology, USA

Sabrina Sartori, University of Oslo, Norway

Magaly Spector, The University of Texas at Dallas, USA

Molly M. Stevens, Imperial College London, UK

Anke Weidenkaff, University of Stuttgart, Germany

\section{MRS OPERATING COMMITTEE CHAIRS}

Academic Affairs Bruce M. Clemens, Stanford University, USA

Awards Albert Polman, FOM Institute AMOLF, The Netherlands

Government Affairs Kevin J. Whittlesey, 4D Molecular Therapeutics, USA

Meetings Terry Aselage, Sandia National Laboratories, USA

Member Engagement Sossina M. Haile, Northwestern University, USA

Public Outreach Elizabeth Kupp, The Pennsylvania State University, USA

Publications Shefford Baker, Cornell University, USA

\section{MRS HEADQUARTERS}

Todd M. Osman, Executive Director

J. Ardie Dillen, Director of Finance and Administration

Damon Dozier, Director of Government Affairs

Patricia Hastings, Director of Meetings Activities

Eileen M. Kiley, Director of Communications
Editor

Gopal R. Rao, rao@mrs.org

Managing Editor

Lori A. Wilson, Iwilson@mrs.org

News Editor

Judy Meiksin, meiksin@mrs.org

Technical Editor

Lisa C. Oldham, oldham@mrs.org

Editorial Assistants

Michelle S. Raley, raley@mrs.org

Mary Wilmoth

Associate Technical Editor

Carol Tseng

Production/Design

Andrea Pekelnicky-Frye, Rebecca Tokarczyk,

Felicia Turano, and TNQ

Associate Production Editor

Katie Wurtzel

Principal Development Editor

Elizabeth L. Fleischer

Director of Communications

Eileen M. Kiley
Guest Editors

Mark Bathe and Paul W.K. Rothemund

Special Consultant

Angelika Veziridis

Energy Quarterly

George Crabtree (Co-chair),

Elizabeth A. Kócs (Co-chair)

Andrea Ambrosini, Monika Backhaus,

David Cahen, Russell R. Chianelli,

Shirley Meng, Sabrina Sartori, Anke

Weidenkaff, M. Stanley Whittingham,

and Steve M. Yalisove

Advertising/Sponsorship

Mary E. Kaufold, kaufold@mrs.org

Donna L. Watterson, watterson@mrs.org

Member Subscriptions

Michelle Judt, judt@mrs.org

Non-Member Subscriptions

subscriptions_newyork@cambridge.org
EDITORIAL BOARD

Fiona C. Meldrum (Chair), University of Leeds, UK

V.S. Arunachalam, Center for Study of Science, Technology \& Policy, India

Christopher J. Bettinger, Carnegie Mellon University, USA

Igor Lubomirsky, Weizmann Institute, Israe

Amit Misra, University of Michigan, USA

Steven C. Moss, The Aerospace Corporation, USA (retired)

Julie A. Nucci, Cornell University, USA

Linda J. Olafsen, Baylor University, USA

James W. Stasiak, HP Inc., USA

Carol Trager-Cowan, University of Strathclyde, UK

Eric Werwa, Washington, DC, USA

M. Stanley Whittingham, Binghamton University, The State University of New York, USA

Steve M. Yalisove, University of Michigan, USA

\section{VOLUME ORGANIZERS}

2017 Ken Haenen, Hasselt University \& IMEC vzw, Belgium John C. Mauro, The Pennsylvania State University, USA Michael S. Strano, Massachusetts Institute of Technology, USA Joyce Y. Wong, Boston University, USA

2018 Karsten Albe, Technische Universität Darmstadt, Germany Hiroshi Funakubo, Tokyo Institute of Technology, Japan Michael Hickner, The Pennsylvania State University, USA Bethanie Stadler, University of Minnesota, USA

2019 Craig B. Arnold, Princeton University, USA Claus Daniel, Oak Ridge National Laboratory, USA Seung Min Han, KAIST, South Korea Gabe Montano, Los Alamos National Laboratory/Northern Arizona University, USA

MRS Bulletin (ISSN: 0883-7694, print; ISSN 1938-1425, online) is published monthly by the Materials Research Society, 506 Keystone Drive, Warrendale, PA 15086-7573. @ 2017 Materials Research Society. Permission required to reproduce content. Periodical postage paid at New York, NY, and at additional mailing offices. POSTMASTER: Send address changes to MRS Bulleti in care of the Journals Department, Cambridge University Press, 100 Brook Hill Drive, West Nyack, NY 10994-2113, USA. Printed in the U.S.A.

Membership in MRS is $\$ 130$ annually for regular members, $\$ 32$ for students, and includes an electronic subscription to MRS Bulletin. Print subscriptions are available to MRS members for an additional $\$ 25$. Individual member subscriptions are for personal use only. Non-member subscription rates are $\$ 533$ (USD) for one calendar year (12 issues). Requests from subscribers for missing journal issues will be honored without charge only if received within six months of the issue's actual date of publication.

MRS Bulletin is included in Current Contents $\otimes /$ Engineering, Computing, and Technology; Current Contents ${ }^{\oplus / P h y s i c a l, ~ C h e m i c a l, ~ a n d ~ E a r t h ~ S c i e n c e s, ~ t h e ~ S c i S e a r c h ~}{ }^{\circledast}$ online database, Research Alert ${ }^{\oplus}$, Science Citation Index $x^{\oplus}$, and the Materials Science Citation Index ${ }^{\top M}$. Back volumes of MRS Bulletin are available on microfiche through University Microfilms Inc., 300 North Zeeb Road, Ann Arbor, MI 48106, USA.

Authors of each technical article appearing in MRS Bulletin are solely responsible for all content in their article(s), including accuracy of the facts, statements, and citing resources. Facts and opinions are solely the personal statements of the respective authors and do not necessarily represent the views of the editors, the Materials Research Society, or Cambridge University Press.

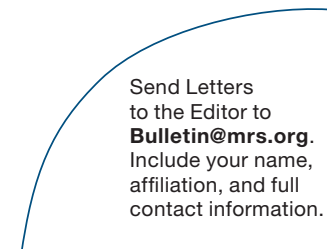




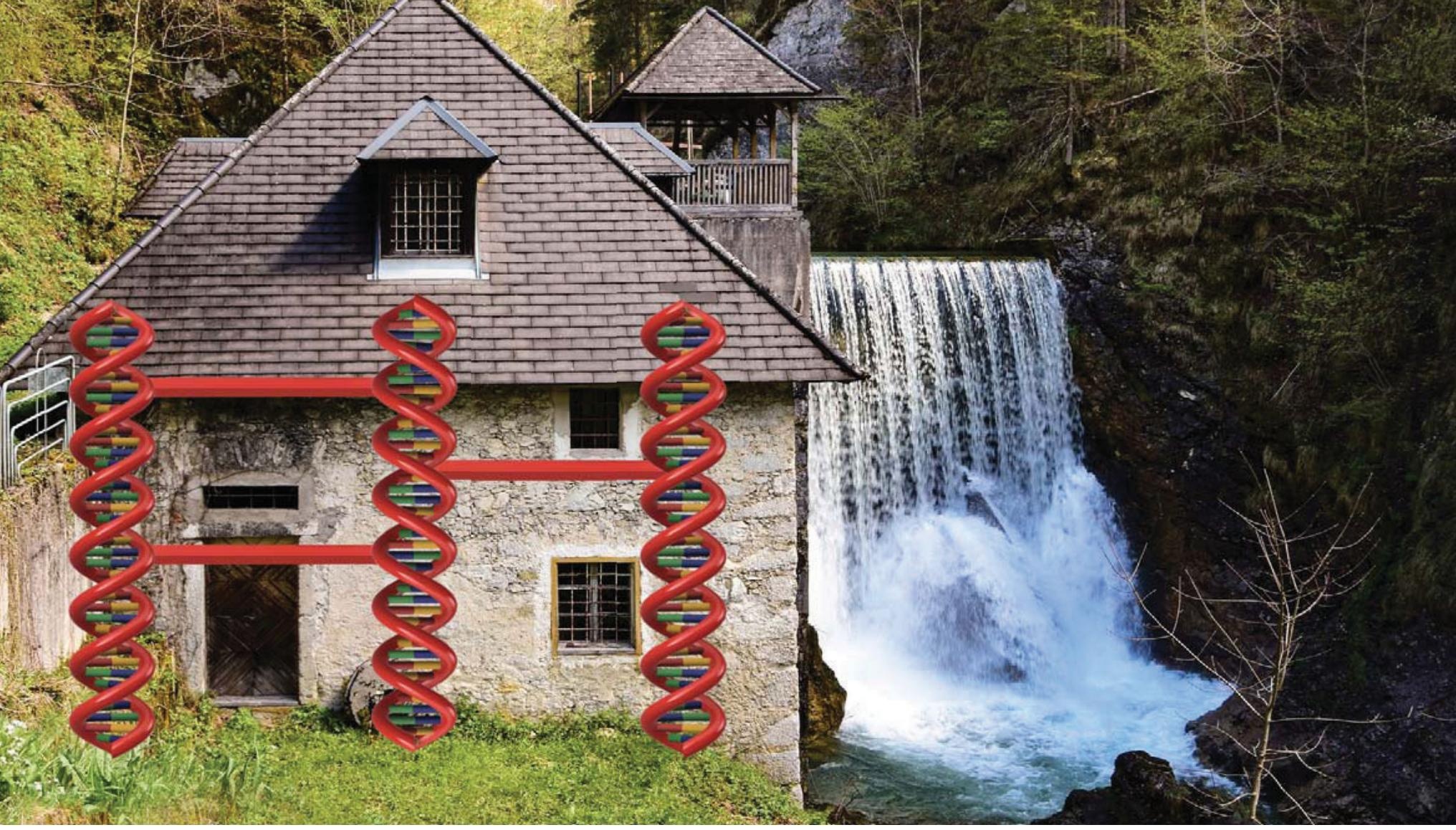

\section{Are all ssDNA scaffolds created equal?}

The short answer: No.

Whether you make or buy your ssDNA scaffold, the quality of the input will be a major factor on your finished nanostructure product. Please visit Guild BioSciences' website to view our study comparing Guild BioSciences' FOUNDATION ${ }^{\mathrm{TM}}$ sSDNA Scaffold to other scaffolds on the market.

Guild BioSciences offers quality, low cost FOUNDATION ${ }^{\mathrm{TM}}$ SSDNA Scaffold for the DNA origami research community. Current scaffolds include: 7249 (M13mp18), 7308, and 8064. Follow us on LinkedIn ${ }^{\circledR}$ to be informed of new scaffolds and related products.

Made in the USA. For Research Use Only.
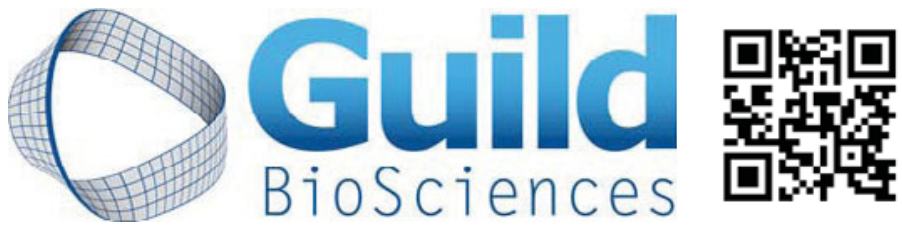

info@guildbiosciences.com www.guildbiosciences.com/foundation_ssdna 